\title{
Numerical and Experimental Study on the Combustion and Emission Characteristics of a Dimethyl Ether (DME) Fueled Compression Ignition Engine
}

\author{
Hyung Jun Kim?', Sung Wook Park ${ }^{2}$ and Chang Sik Lee ${ }^{*}$ \\ 1 National Institute of Environmental Research, Gyeongseo-dong, Seo-gu, Inchon, 404-704 - Republic of Korea \\ 2 Department of Mechanical Engineering, Hanyang University, 17 Haengdang-dong, Seongdong-gu, Seoul, $133-791$ - Republic of Korea \\ e-mail: junandjin@korea.kr - parks@hanyang.ac.kr -cslee@hanyang.ac.kr \\ * Corresponding author
}

\begin{abstract}
Résumé - Études numériques et expérimentales sur les caractéristiques de combustion et d'émissions d'un éther diméthylique (EDM)- moteur à auto-allumage rempli de combustible Dans cette étude, nous considérons la simulation de la combustion du dimethyl ether (DME) dans un moteur à allumage par compression. Les caractéristiques de la combustion ainsi que les émissions polluantes sont analysées sur une large gamme d'avance à l'injection. Afin de simuler le processus de combustion du EDM, le code KIVA-3V couplé à un solveur chimique a été utilisé pour résoudre la cinétique détaillée de l'oxydation du EDM. Le modèle de rupture de Kelvin-Helmholtz-RayleighTaylor (KH-RT) ainsi que le modèle de turbulence k- $\varepsilon$ RNG ont été appliqués pour analyser respectivement les caractéristiques du jet et l'écoulement turbulent. Pour prévoir la formation de $\mathrm{NO}_{x}$ pendant la combustion du EDM, le mécanisme réduit du GRI a été employé. Les résultats de simulation pour la combustion et les émissions polluantes ont été comparés aux résultats expérimentaux dans les mêmes conditions de fonctionnement. Concernant les calages de combustion, la pression moyenne simulée et les taux de chaleur dégagée sont en bon accord avec les résultats expérimentaux. Les niveaux d'émissions de $\mathrm{NO}_{x}$ expérimentaux ont été réduits à mesure que l'injection est retardée ; cette tendance est correctement reproduite par la simulation. Enfin, les prédictions sur les émissions en monoxyde de carbone et en hydrocarbure montrent une tendance croissante à mesure que l'injection est retardée.
\end{abstract}

\footnotetext{
Abstract - Numerical and Experimental Study on the Combustion and Emission Characteristics of a Dimethyl Ether (DME) Fueled Compression Ignition Engine - A numerical investigation was carried out to study on the combustion and emission characteristics of dimethyl ether (DME) with wide ranges of injection timings in compression ignition engines. In order to simulate DME combustion processes, a KIVA-3V code coupled with a chemistry solver was used to solve the detailed chemical kinetics model of DME oxidation. In addition, the Kelvin-Helmholtz-Rayleigh-Taylor (KH-RT) hybrid breakup model and Renormalization Group $(R N G) k$ - $\varepsilon$ models were applied to analyze the spray characteristics and turbulent flow, respectively. To predict the $N O_{x}$ formation during DME combustion, a reduced Gas Research Institute (GRI) NO mechanism was used. From these results on the combustion and emission, the calculated results were compared with experimental ones for the same operating conditions. In the combustion characteristics, the calculated combustion pressure and
} 
heat release rates agreed well with experimental results. The levels of experimental $N O_{x}$ emissions was reduced as the start of the injection timing retarded, and also these trends appeared in calculated emission characteristics. Additionally, the calculated CO and HC emissions show an increasing trend as the start of the injection is retarded.

\section{INTRODUCTION}

Dimethyl ether (DME) is a promising alternative fuel for conventional diesel engines due to significant advantages compared to diesel fuel and it is known as an environmentally friendly energy source. Recently, DME can be produced from natural gas and coal, as well as recyclable sources and garbage. The molecular structure of DME is a simple ether $\left(\mathrm{CH}_{3} \mathrm{OCH}_{3}\right)$ with a high cetane number between 55 and 60 and this fuel is sufficient for compression ignition engines. In addition, properties of DME fuel demonstrate low auto-ignition temperature and lower LHV (Lower Heating Value) than those of diesel fuel. Furthermore, the level of the Particulate Matter (PM) after the combustion of DME fuel is remarkably decreased because it has no direct combination between carbon and carbon. The nitrogen oxide $\left(\mathrm{NO}_{x}\right)$ emissions of DME engines also can be reduced through application of the optimal Exhaust Gas Recirculation (EGR) ratio. However, it is necessary to modify partly the fuel supply and injection system because materials such as crude and synthetic rubber used for sealing fuel supply systems expand and melt when they have contact with DME fuel. For these reasons, DME fuel has different characteristics of spray, combustion, and emissions compared to the conventional diesel fuel. Therefore, many researchers (Arcoumanis et al., 2008; Tsutsumi et al., 2009; Jung et al., 2009) have experimentally and numerically investigated for the application of DME fuel in diesel engines.

Experimental and numerical studies on diesel, biodiesel, and DME spray characteristics were performed by Kim H.J. et al. (2008a, 2009). They reported that the experimental results of the spray development process and its axial distance from nozzle tip were in agreement with calculated results obtained by using the KIVA-3V code. Also, DME had better atomization performance than the diesel and biodiesel fuel. Additionally, many researches (Kim H.J. et al., 2008b; Sidu et al., 2001; Jun et al., 2001) showed that the spray tip penetration of diesel spray was longer than that of DME spray, and that DME spray evaporated more quickly. The experimental researches on the spray and combustion characteristics of DME fuel in a compression ignition engine equipped with a common-rail injection system were performed by Kim M.Y. et al. (2007a, 2008). They revealed that ignition timing and combustion duration of DME fuel were more advanced and shorter than those of diesel fuel, respectively. In addition, $\mathrm{NO}_{x}$ emission increased, but carbon oxide (CO) and hydrocarbon (HC) emissions were greatly reduced when using DME fuel instead of conventional diesel fuel. In addition to the experimental investigations on the DME fueled diesel engine, numerical studies on the combustion and emission characteristics of DME fuel have been performed using a detailed chemical kinetic mechanism of DME. Konno et al. (2003) conducted a computational and experimental study using a single cylinder test engine fueled with DME fuel. They observed that DME oxidation at the Homogenous Charge Compression Ignition (HCCI) combustion is controlled by the production and consumption behavior of $\mathrm{OH}$ radicals. Through a modeling study on the combustion and emission characteristics of directinjection diesel engines fueled with DME fuel, Gui et al. (2004) revealed that the maximum combustion pressure and pressure rise rates of DME in the diesel engine were lower than those of conventional diesel fuel. Simulations using the KIVA-3V code coupled with detailed chemical kinetics on the combustion and emissions for a DME fueled direct injection diesel engine were conducted by Elkelawy et al. (2008) and Zhang et al. (2007). These groups reported that the DME combustion process includes the two stage heat releases at high and low temperature stages. In addition, methyl radicals and formaldehyde have tremendous impacts on the high and low temperature reactions, respectively. In order to reduce the original detailed chemical kinetics, simplified and reduced chemical kinetic mechanisms for the DME oxidation in the diesel engine have been developed by many researchers (Kim H. et al., 2003; Yamada et al., 2003; Mo et al., 2007; Mittal et al., 2008) to reduce calculation time. Various reduced chemical kinetic models were developed and these models were compared with a detailed chemical kinetic model for the validation of DME combustion using a sensitivity analysis over a wide range of temperatures.

Despite experimental studies and simulations on DME combustion in diesel engines, uncertainties including specifics of engine performance and emission characteristics of DME engines compared to diesel engines remains. To achieve this purpose, systematic investigations on the combustion processes and emission formation in High Speed Direct Injection (HSDI) diesel engines are required.

In this paper, the investigations on the modeling of the combustion and emission characteristics of DME fuel for a range of starts of the injection timing in a single cylinder diesel engine with high-pressure injection system were conducted by using the KIVA-3V code coupled with a detailed DME oxidation mechanism. The calculated results, such as combustion pressure, heat release rate, and exhaust emissions were compared to experimental results under various injection timings. 


\section{MODEL FORMULATION}

\subsection{Calculation Model}

In the present study, calculations were carried out by using the KIVA-3V release 2 code (Amsden, 1999) for analyzing combustion and emission characteristics for a diesel engine fueled with DME fuel. The KIVA code has been widely used to analyze the combustion and emission formation processes in the cylinder of a diesel engine (Kim H.J. et al., 2008c; Park and Reitz, 2007, 2009; Sun and Reitz, 2006). In order to compare the combustion characteristics between diesel and DME fuel, a tetradecane $\left(\mathrm{C}_{14} \mathrm{H}_{30}\right)$ with similar physical properties of conventional diesel fuel was applied. Based on the detailed $n$-heptane mechanism including 250 species and 576 reactions, a reduced ERC $n$-heptane mechanism (Patel et al., 2004) consisting of 36 species and 74 reactions was used to simulate the diesel fuel oxidation processes.

Additionally, investigations on the DME fuel properties, such as surface tension, viscosity, latent heat, density, enthalpy, and vapor pressure were conducted by Teng et al. (2001, 2002, 2003, 2004, 2005) for the inclusion of DME fuel in the fuel library. On the basis of existing chemical equations and molecular theory, various equations describing DME fuel properties were developed, and the temperature and pressure figured into a diagram for design and modeling of a liquefied DME fuel system. A liquefied DME fuel library was provided to KIVA code based on previously calculated DME properties that vary with respect to temperature.

The modified Renormalization Group (RNG) $k$ - $\varepsilon$ model (Han and Reitz, 1999) was used to calculate the turbulence for flow compressibility in the cylinder and the $\varepsilon$ term of the standard $k-\varepsilon$ model was modified in order to solve problems such as the very low Mach number of an in-cylinder flow and fluid with large density variations by moving piston. The Kelvin-Helmholtz (KH) and Rayleigh-Taylor (RT) hybrid model (Beale and Reitz, 1999) was used for modeling atomization and the breakup processes of DME spray injected directly into the cylinder. Also, the spray-wall interaction model (O'Rourke and Amsden, 2000) including droplet splash and impingement-pressure spreading was utilized to analyze the impingement process between the fuel droplets and cylinder wall. To simulate ignition and combustion processes of DME fuel, KIVA code coupled with the Chemkin II chemistry solver (Kee et al., 1989) was used to solve the chemical reactions of DME oxidation during the combustion process in the diesel engine. The detailed chemical kinetics model (Fischer et al., 2000; Curran et al., 2000) of DME combustion consisting of 79 species and 351 reactions were applied to simulate the DME combustion process more accurately. The chemical kinetic studies of dimethly ether oxidation according to the ambient pressure and temperature were conducted by Dagaut et al. $(1996,1998)$. In addition, the detailed chemical kinetics model was applied to analyze the DME combustion in the compression ignition engine and these researches (Kong, 2007; Yamada et al., 2005; Zheng et al., 2005) have actively progressed.

In order to predict $\mathrm{NO}_{x}$ emissions during the combustion process, the $\mathrm{NO}_{x}$ formation process was modeled using a reduced Gas Research Institute (GRI) NO mechanism (Kong et al., 2007). The reduced GRI mechanism was reduced from the original GRI NO mechanism (Smith et al., 2000), which is composed of 101 reactions among 22 species related to nitric oxides. Consequently, the reduced GRI NO mechanism including the four species $\left(\mathrm{N}, \mathrm{NO}, \mathrm{N}_{2} \mathrm{O}, \mathrm{NO}_{2}\right)$ and nine reactions, was added to the fuel oxidation mechanism because the detailed chemical kinetics model of the DME oxidation did not account for the $\mathrm{NO}_{x}$ formation process. In addition, other emissions (e.g., $\mathrm{HC}, \mathrm{CO}_{2}$ ) could be calculated from the detailed reaction mechanism of the DME oxidation process. Soot emissions seldom appear from diesel engines fueled with DME fuel (Kim M.Y. et al., 2007a; Gui et al., 2004). Therefore, the soot formation process was not modeled in the present study.

\subsection{Detailed Chemical Kinetics Model for the DME Oxidation}

The detailed chemical kinetics model for the low and high temperature reactions suggested by Curran et al. (2000) was used to simulate the ignition and combustion processes of DME fuel. Curran et al. developed a computational model of the DME overall oxidation mechanism composed of 351 reversible elementary reactions among 79 species that is based on the experimental results of observed ignition delay in a shock tube and stirred reactor. The overall reaction scheme for DME oxidation is illustrated in Figure 1. The major paths of DME oxidation are constructed from dehydrogenation, $\beta$-scission of the $\mathrm{C}-\mathrm{O}$ bond, and isomerization . Below $800 \mathrm{~K}$, the low temperature mechanism (blue arrow) initiated from the dehydrogenation of DME fuel $\left(\mathrm{CH}_{3} \mathrm{OCH}_{3}\right)$ and the hydroperoxy-methoxymethyl radical $\left(\mathrm{CH}_{2} \mathrm{OCH}_{2} \mathrm{O}_{2} \mathrm{H}\right)$ was formed from the methoxymethyl radical $\left(\mathrm{CH}_{3} \mathrm{OCH}_{2}\right)$ via the addition to molecular oxygen and isomerization. The $\mathrm{CH}_{2} \mathrm{OCH}_{2} \mathrm{O}_{2} \mathrm{H}$ species were divided into two molecules of formaldehyde producing $\mathrm{OH}$ radical by $\beta$-scission. In addition, $\mathrm{OH}$ radicals increase with the addition to molecular oxygen leading to chain branching. The oxidation ratio reduces, and the $\mathrm{CO}, \mathrm{CO}_{2}, \mathrm{H}$ and $\mathrm{HCO}_{2}$ produced by the isomerization and $\beta$-scission as the temperature increases due to the reaction heat. Alternatively, the methoxy $\left(\mathrm{CH}_{3} \mathrm{O}\right)$ and methyl radical $\left(\mathrm{CH}_{3}\right)$ were formed by unimolecular fuel decomposition during DME pyrolysis within the high temperature mechanism (red arrow) (Fischer et al., 2000). Additionally, the methoxymethyl radical $\left(\mathrm{CH}_{3} \mathrm{OCH}_{2}\right)$ after the dehydrogenation of the DME fuel decomposed into formaldehyde $\left(\mathrm{CH}_{2} \mathrm{O}\right)$ and a methyl radical by $\beta$-scission. Therefore, the DME oxidation mechanisms at low and high temperature make 

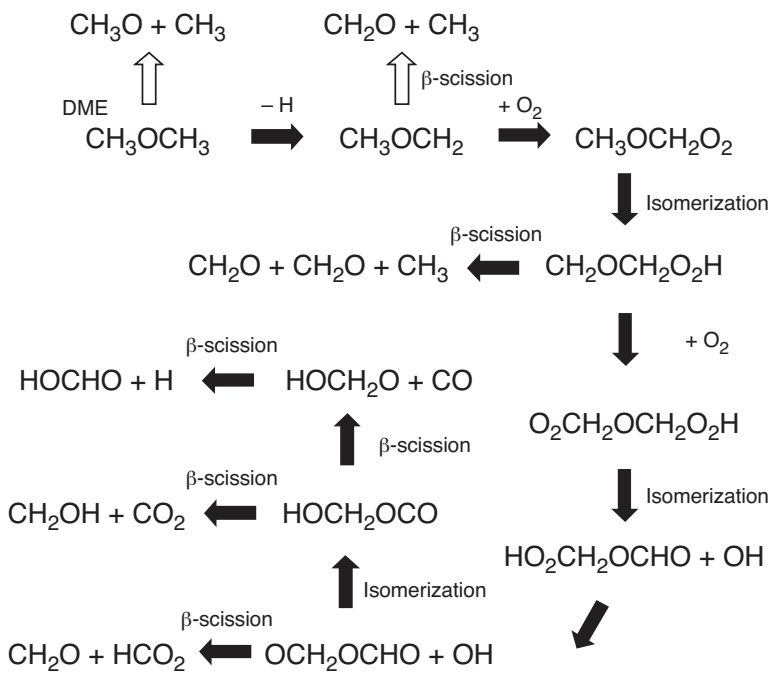

$\Rightarrow$ Low temperature mechanism

$\Longrightarrow$ High temperature mechanism

Figure 1

Detailed chemical kinetics mechanism of the DME oxidation process (Curran et al., 2000).

progress by detailed chemical kinetics reactions as per the above statements.

\subsection{Engine Specifications and Calculation Conditions}

In order to validate the present models, experimental results (Kim M.Y. et al., 2007a, b, 2008; An et al., 2007) obtained from the four valves DI single cylinder diesel engine with a high-pressure injection system were used. The detailed engine specifications and fuel injection system are illustrated in Table 1. Figure 2 shows the computational grid at BTDC (before top dead center) 40 degrees and injection velocity at the injection pressure of $50 \mathrm{MPa}$ with time. In addition, the coarse and fine grids were created for the evaluation of details of spatial distribution of the in-cylinder parameters. The unit cell size of coarse and fine grid mesh is approximately $2 \mathrm{~mm}^{3}$ and $1 \mathrm{~mm}^{3}$, respectively. A computation grid with a 60 degrees sector mesh was generated for the reduction of calculation time. The crevice volume at the piston wall was designated for the adjustment of the effective compression ratio. In addition, the injection velocity profile was provided to the KIVA code for the accurate analysis of DME spray and combustion characteristics. For analyzing combustion and emission characteristics at various injection timings from BTDC 12 to 6 degrees, calculations were performed by using the KIVA-3V code at the same operating conditions. Detailed operating conditions such as injection pressure, mass, and engine speed are listed in Table 2. The wall
TABLE 1

Fuel injection system and engine specifications

\begin{tabular}{l|l}
\hline \multicolumn{2}{c}{ Fuel injection system } \\
\hline Injection system & $\begin{array}{l}\text { Bosh common-rail system } \\
\text { Number of nozzle holes }\end{array}$ \\
$\begin{array}{l}\text { Nozzle diameter } \\
\text { Spray angle }\end{array}$ & $0.128 \mathrm{~mm}$ \\
\hline \multicolumn{2}{c}{ Single cylinder diesel engine } \\
\hline \multicolumn{2}{c}{ Direct injection } \\
Engine type & diesel engine with 4 valves \\
Bore $\times$ Stroke & $75.5 \times 84.5$ mm \\
Displacement volume & $373.3 \mathrm{~cm}^{3}$ \\
Compression ratio & $17.8: 1$ \\
Piston shape & Re-entrant type \\
Intake Valve Close timing (IVC) & BTDC 128 degrees \\
Exhaust Valve Open timing (EVO) & ATDC 172 degrees \\
\hline
\end{tabular}

a)
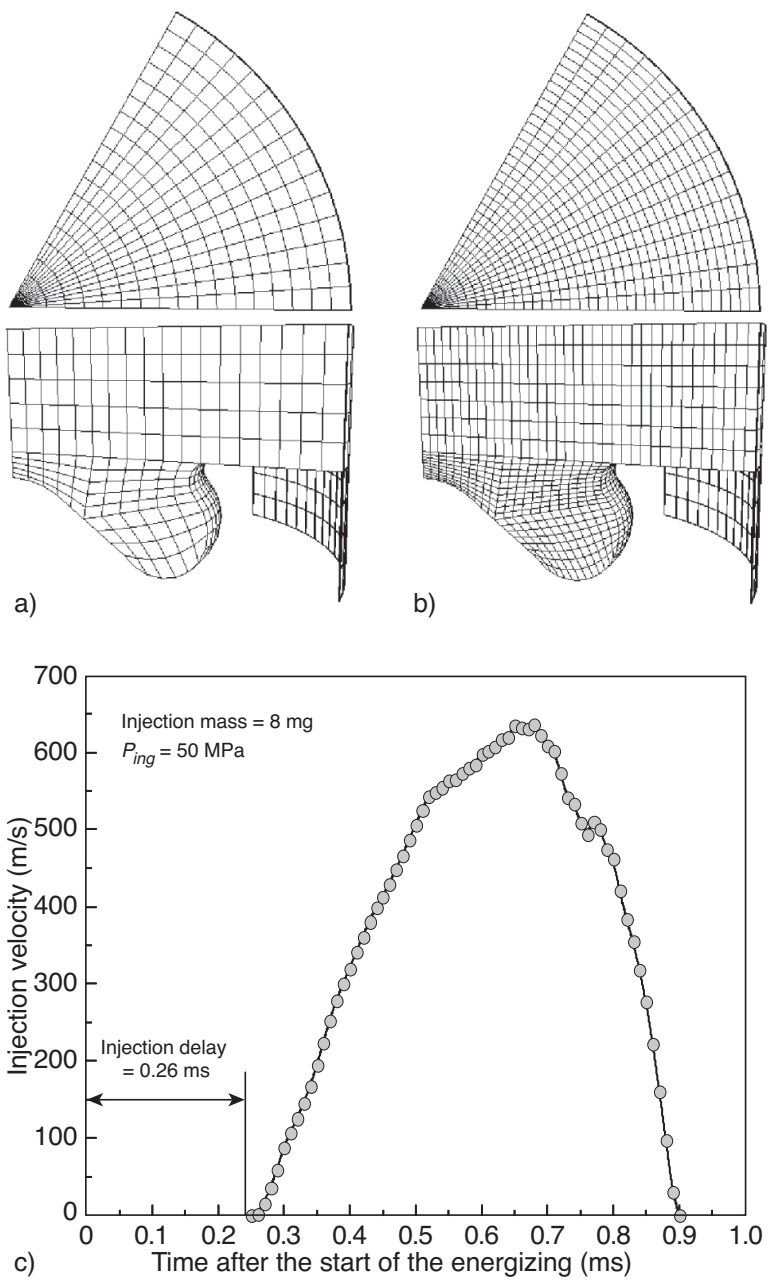

Figure 2

Computational meshes at BTDC 40 degrees and injection velocity according to time after the start of the injection. a) $60^{\circ}$ sector mesh (coarse grid mesh); b) $60^{\circ}$ sector mesh (fine grid mesh); c) injection velocity. 
TABLE 2

\begin{tabular}{l|c}
\multicolumn{2}{c}{ Operating conditions } \\
\hline Engine speed & $1500 \mathrm{rpm}$ \\
\hline Fuel & Dimethyl ether $\left(\mathrm{CH}_{3} \mathrm{OCH}_{3}\right)$ \\
\hline Injection pressure & $50 \mathrm{MPa}$ \\
\hline Injected fuel mass & $8 \mathrm{mg} / \mathrm{stroke}$ \\
\hline Start Of Injection (SOI) & $12,10,8,6^{\circ} \mathrm{BTDC}$ \\
\hline Intake temperature & $320 \mathrm{~K}$ \\
\hline Swirl ratio & 1.63 \\
\hline
\end{tabular}

temperatures of piston, head and cylinder are determined to be $553 \mathrm{~K}, 523 \mathrm{~K}$ and $433 \mathrm{~K}$, respectively. And the calculation time step was set constant at $0.1 \mu$ s for the accurate prediction. In order to analyze the DME spray, the size and time constant of the KH breakup model were adjusted to 1.0 and 40 , respectively based on the suggested model constants (Kim H.J. et al., 2009) obtained from evaluation of breakup model for DME spray. The breakup constants of the droplet size and time in the RT model were determined as 0.1 and 1.0 , respectively. Also, the total numbers of injected droplets and fuel temperature were decided as 2000 and $363 \mathrm{~K}$. In addition, computations in the closed system were conducted from the Intake Valve Close (IVC) timing to the Exhaust Valve Open (EVO) timing.

\section{RESULTS AND DISCUSSION}

\subsection{Combustion and Emission Characteristics of a DME Engine Compared to an Engine using Conventional Diesel Fuel}

The calculated combustion and emissions characteristics in a diesel engine fueled with DME fuel are validated by experimental results obtained at $50 \mathrm{MPa}$ injection pressure, BTDC 10 degree injection timing, and an $8 \mathrm{mg}$ injection mass.

Figures 3 and 4 show a comparison between the experimental and calculated combustion and emission characteristics at baseline condition. In addition, the injection mass of diesel fuel was adjusted to keep the calorific heat release between the two fuels in this study. The diesel fuel mass was applied to the modified fuel mass of $5.4 \mathrm{mg}$ in consideration of low LHV of DME fuel. In combustion characteristics, the calculated combustion pressure of the DME fueled engine agrees well with experimental results. However, the predicted peak value of the heat release rate is greater than that of the experimental result mainly because the calculated heat release does not include heat losses from heat transfer to the wall. The combustion pressure and heat release rates of the diesel fuel have lower peaks than those of
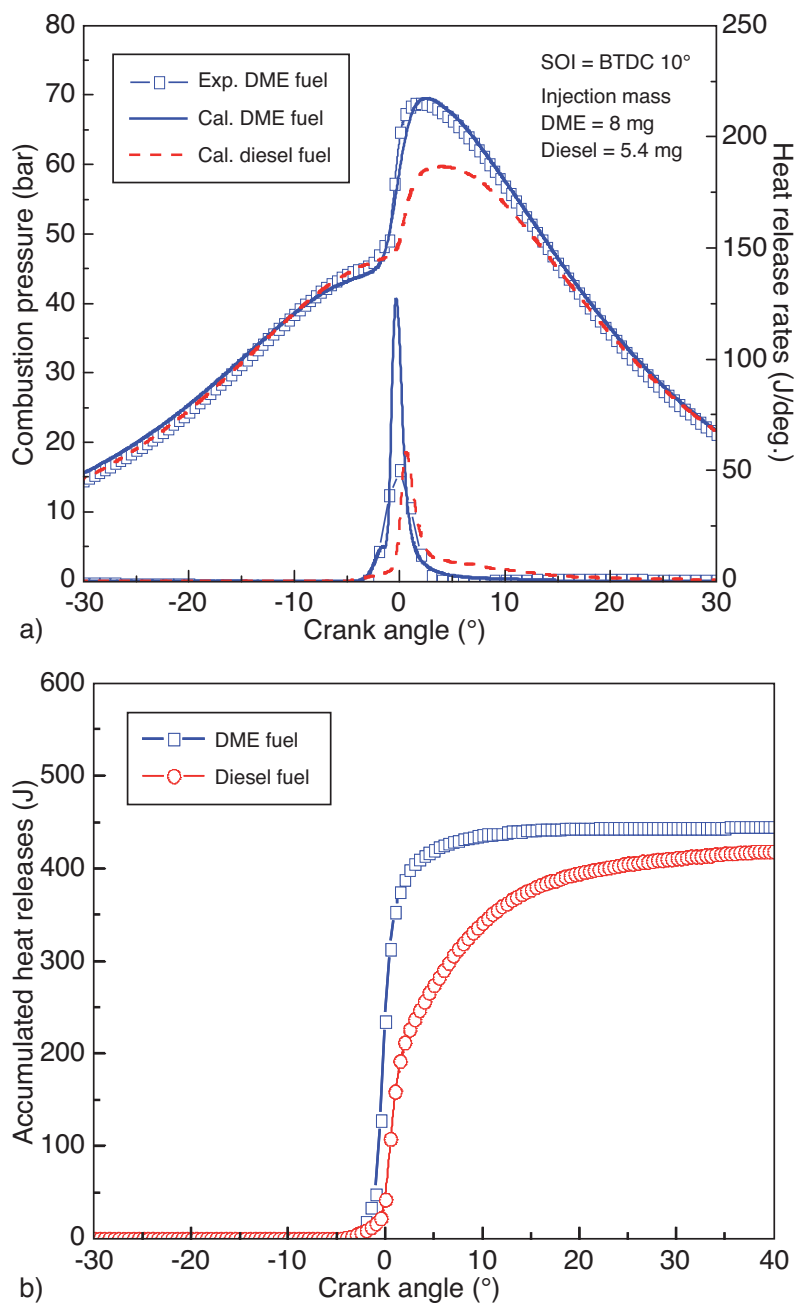

Figure 3

Comparison between experimental and calculated combustion characteristics for the model validation. a) Combustion characteristics; b) accumulated heat releases.

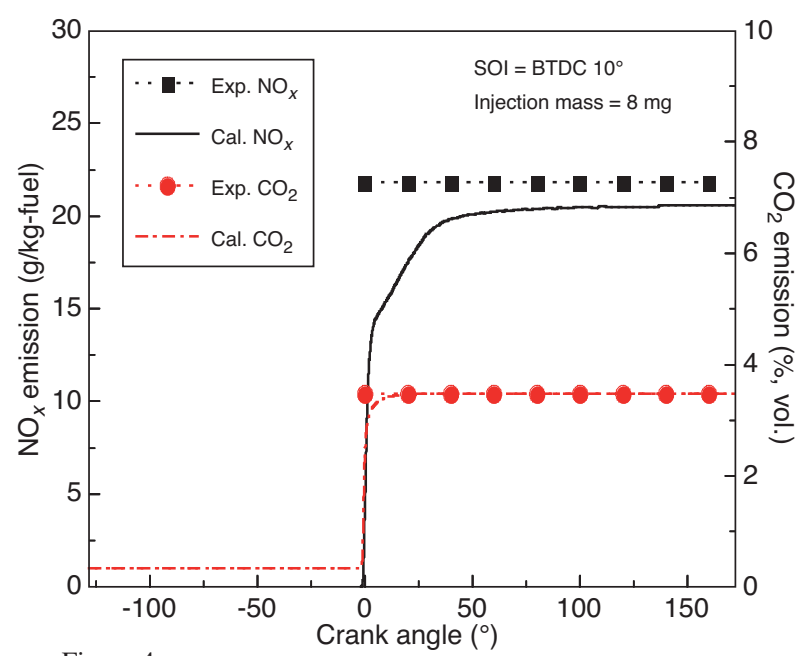

Figure 4

Comparison between experimental and calculated emissions characteristics for the model validation. 


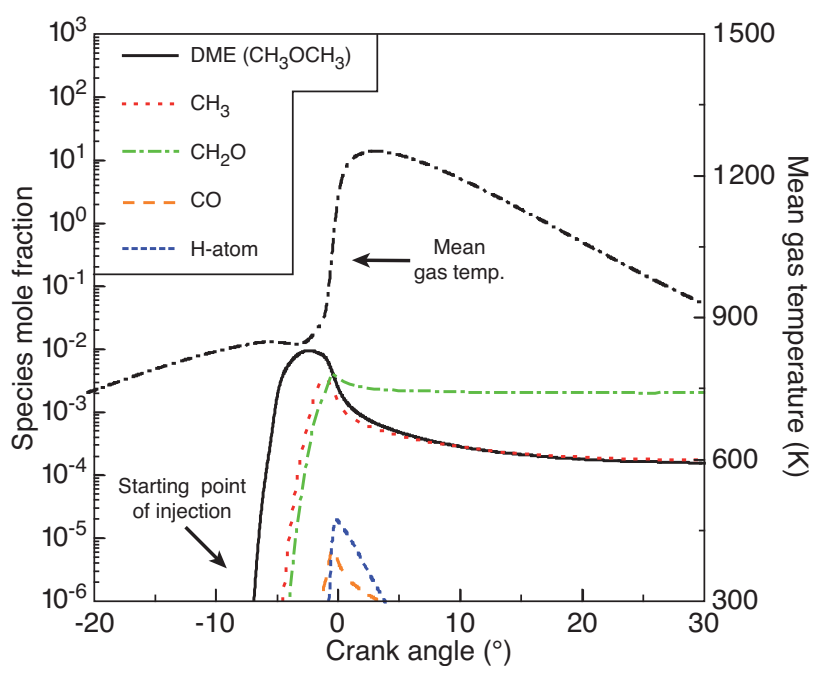

Figure 5

Species mole fractions according to crank angle ( $\mathrm{SOI}=$ BTDC $10^{\circ}$ ).

the DME fuel due to the combustion property of DME fuel under the same calorific value. In addition, the ignition timing of DME fuel is more advanced than that of diesel fuel, as DME fuel has a high cetane number and faster evaporation compared to diesel fuel (Kim M.Y. et al., 2007b, 2008). In the calculated results of accumulated heat releases, the accumulated heat releases of DME fuel are higher than those of diesel fuel for the same calorific value due to the greater injected fuel mass of DME fuel. The accumulated heat releases of DME and diesel fuels become stable from ATDC 5 degrees and 30 degrees, respectively. It is believed that the
DME combustion is more rapid due to faster evaporation of DME fuel compared to diesel fuel. The calculated $\mathrm{NO}_{x}$ and $\mathrm{CO}_{2}$ emissions obtained by the reduced GRI NO mechanism and detailed chemical kinetics model at the start of injection (i.e., $\mathrm{BTDC} 10^{\circ}$ ) are compared to the experimental results in Figure 4. After the start of ignition, $\mathrm{NO}_{x}$ and $\mathrm{CO}_{2}$ emissions rapidly increase and their values remain stable from After Top Dead Center (ATDC) 50 degrees. Also, the calculated $\mathrm{NO}_{x}$ and $\mathrm{CO}_{2}$ emissions show good agreement with experimental results of engine-out emission.

Mole fractions of important species, such as the DME fuel $\left(\mathrm{CH}_{3} \mathrm{OCH}_{3}\right)$, formaldehyde $\left(\mathrm{CH}_{2} \mathrm{O}\right)$, methyl radical $\left(\mathrm{CH}_{3}\right)$, $\mathrm{CO}$, and molecular hydrogen on the DME combustion and mean gas temperature in the cylinder for the BTDC 10 degree injection case, are shown in Figure 5. The mean gas temperature temporarily decreases and the mole fraction of DME fuel increases at the fuel injection timing due to low fuel temperature and evaporation. The mole fractions of formaldehyde and $\mathrm{CO}$ species remarkably are increased by the low temperature mechanism of DME oxidation at the start of combustion. The mean temperature in the cylinder gradually increases due to the high temperature reaction of DME oxidation, in which the DME fuel divides into methoxy and methyl radicals (Elkelawy et al., 2008; Kim H. et al., 2003).

\subsection{Spray and Combustion Characteristics of DME Fuel}

Figure 6 shows the calculated spray and vapor distributions of diesel and DME fuels for the BTDC 10 degree injection according to the crank angle. At BTDC 4 degrees, the injected spray from the nozzle tip develops toward the cylinder bowl and the size of the fuel droplets at the early injection stage

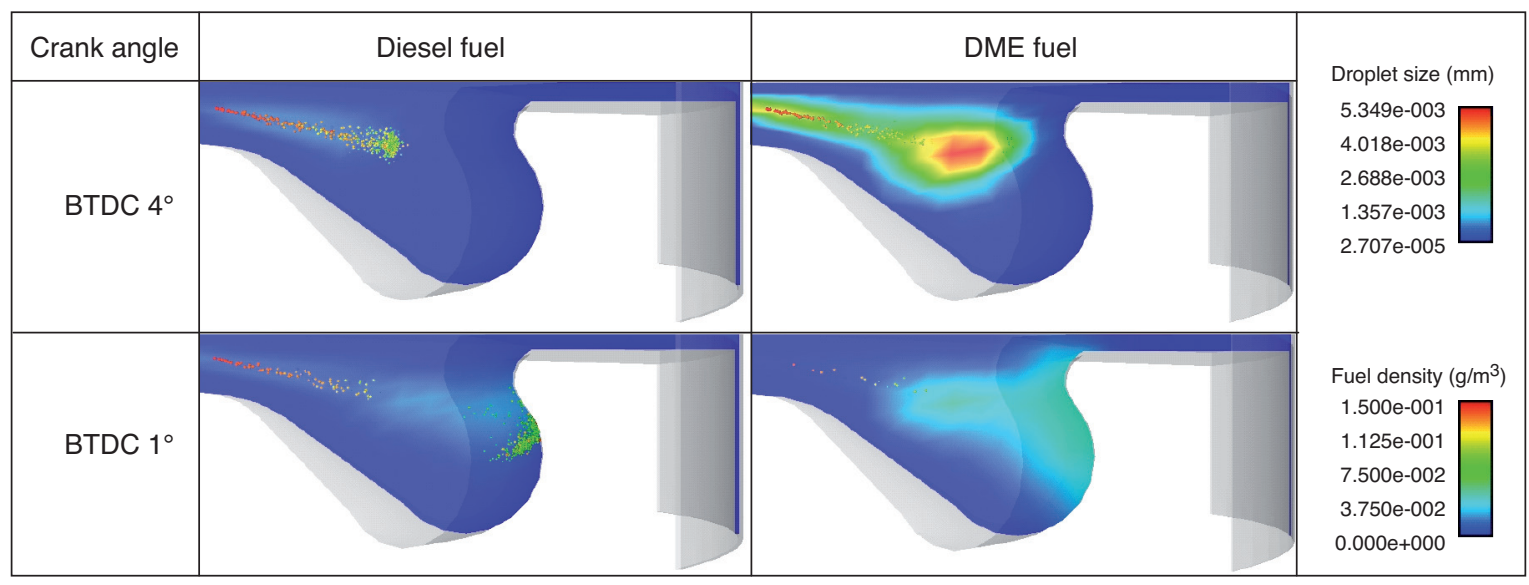

Figure 6

Calculated spray and vapor distributions according to fuel at the BTDC $4^{\circ}$ and BTDC $1^{\circ}$. 
decreases because the high injection velocity at nozzle exit and the ambient conditions with high pressure/temperature promote the atomization of injected droplets. In addition, it is shown that diesel fuel spray impinged on the bowl wall at BTDC 1 degree and fuel after the impingement advances along the bowl wall. However, DME fuel spray is vaporized quickly from the end region of spray due to better atomization of DME spray that results from the lower surface tension and viscosity of DME compared to diesel spray (Kim H.J. et al., 2008b). Moreover, the high vapor pressure of DME promotes the evaporation of injected fuel at the ambient conditions with high temperature and pressure in the cylinder (Kim H.J. et al., 2009; Gui et al., 2004). Therefore, the wall-wetting of diesel spray on the surface of the cylinder
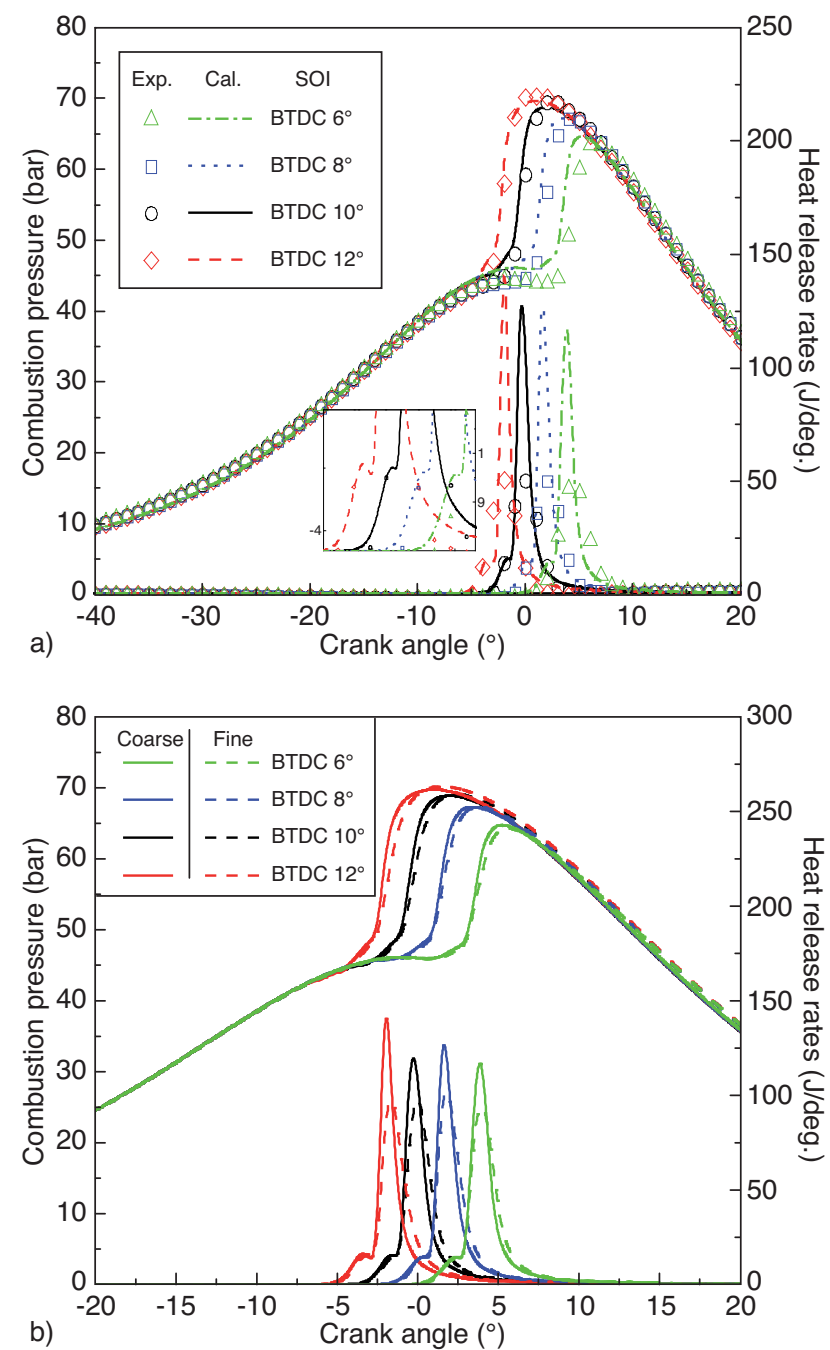

Figure 7

Comparison between experimental and calculated combustion characteristics of both grid meshes according to the start of injection. a) Comparison between the experimental and numerical result (fine grid mesh); b) comparison between the coarse and fine grid mesh. wall was observed by an impingement between the injected fuel and right bowl wall. On the other hand, DME spray is evaporated mostly before impingement with the bowl wall.

Comparisons between the experimental and calculated combustion pressure histories and heat releases rates of DME fuel according to the start of the injection are shown in Figure 7. The operating and calculated conditions of the start of injection varied from BTDC 12 to 6 degrees. The experimental combustion pressure and ignition timing increased and advanced as the start of injection advanced, respectively. The comparison between combustion characteristics in the coarse and fine grid mesh according to the start of the injection was illustrated in Figure 7b. The combustion characteristics in the coarse grid mesh shows a pattern similar to those in the fine grid mesh. However, there are differences in the peak shapes of combustion pressure and heat release rate between the coarse and fine grid mesh. In the combustion pressure, the fine grid mesh shows a slightly lower increasing rate of combustion pressure after the ignition and longer combustion duration than the coarse grid mesh. The injected and evaporated fuel in the fine grid mesh has wide spatial distribution by the effect of the active momentum transfer at the nearest cells. This led to the spread of combustion region and long combustion duration. In addition, the heat release rate in the fine grid mesh shows lower and longer patterns than that in the coarse grid mesh. Therefore, the combustion patterns in the fine grid mesh shows the more accurate prediction compared to the coarse grid mesh. In addition, the pattern of experimental results agrees with calculated results, and also the calculated combustion pressure peak and ignition timing agree with those of experimental results. In the calculated results, a two stage heat releases rate, including low and high temperature reactions, are observed by using the detailed chemical kinetics mechanism of DME oxidation.

Figure 8 shows the calculated combustion temperature distribution of coarse and fine grid meshes in the cylinder at the crank angle of ATDC 4 degrees according to the start of the injection. The flame in the fine grid mesh advanced more along the bowl surface than that in the coarse grid mesh because injected droplets have a fast velocity by effect of dense cells with momentum. Further, this makes the spread of combustion regions and the spatial distribution with high temperature as shown in Figure 8. The injected fuel droplets quickly evaporated around the regions of the right bowl wall because the droplet diameter at the spray tip was reduced by atomization under ambient conditions, and then the evaporated droplets were concentrated in the regions of the right bowl wall by the impingement on the wall. Therefore, DME fuel vapor begins to ignite from the right bowl wall, and the flame is then propagated along the bowl wall. In the top view, the combustion progress shows a clockwise movement with a swirl effect. In addition, the temperature distribution for the injection at the BTDC 12 degrees has a smaller spatial distribution of high temperature region than that at BTDC 6 


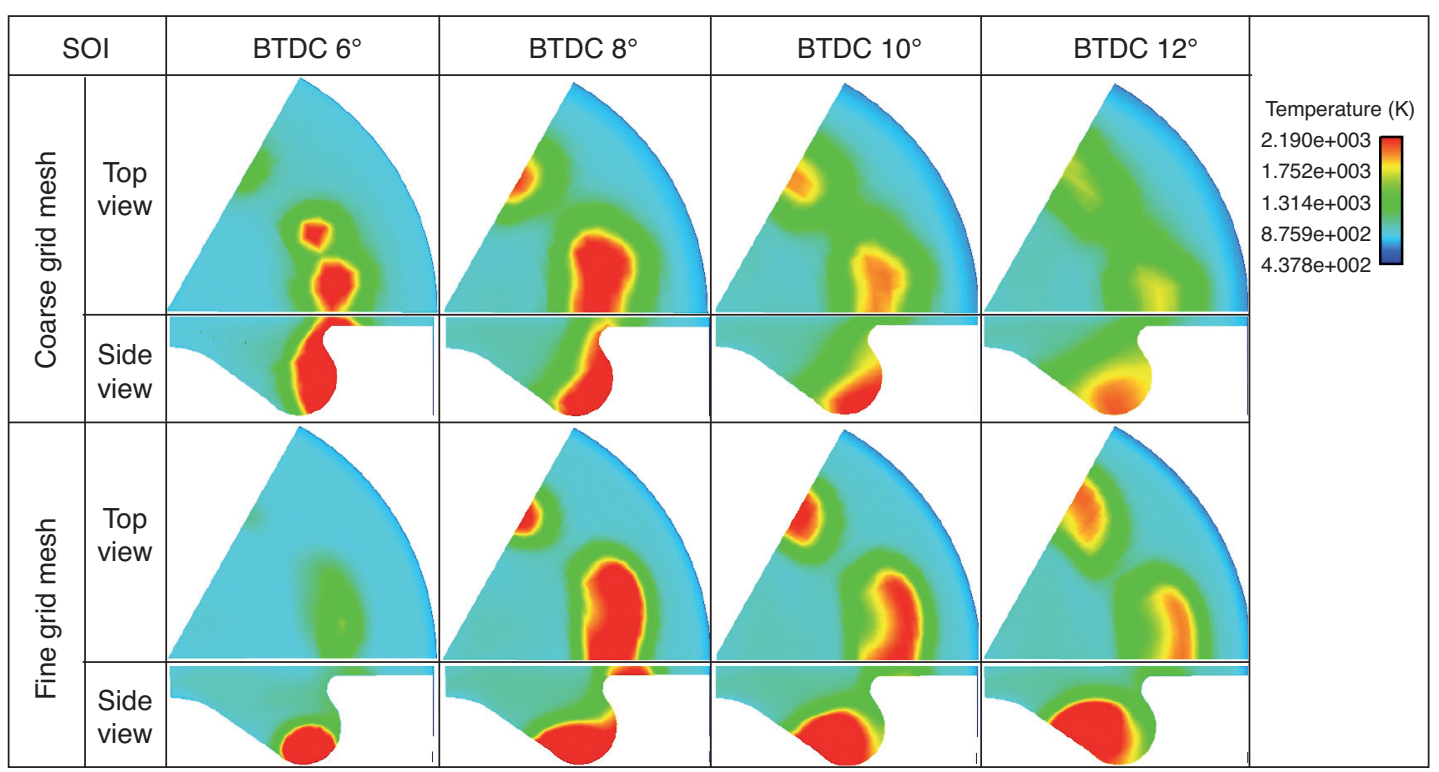

Figure 8

Calculated combustion temperature distribution of coarse and fine grid meshes according to the start of injection (ATDC $4^{\circ}$ ).

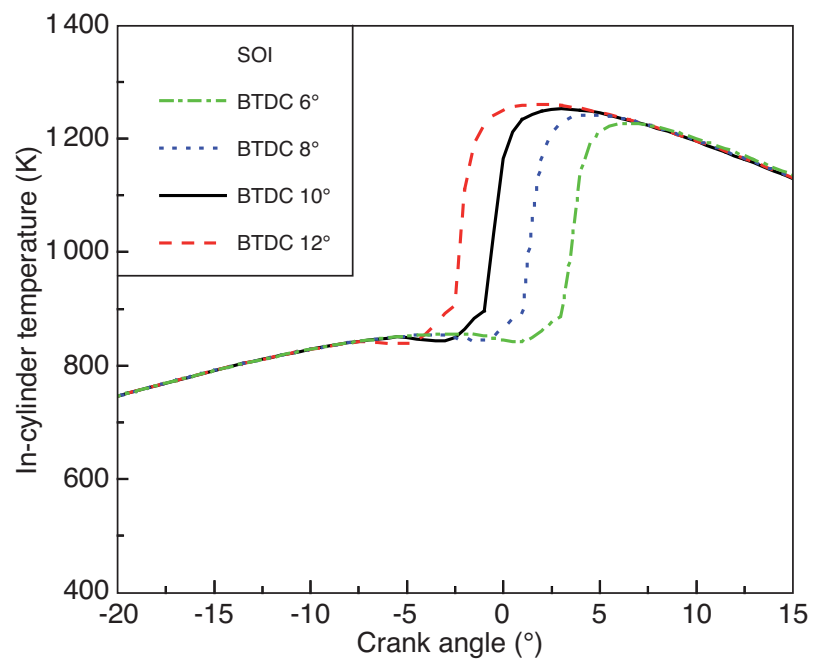

Figure 9

Calculated mean gas temperature in the cylinder according to the start of injection.

degrees.

The effect of the start of injection on the calculated mean gas temperature in the cylinder according to the crank angle is shown in Figure 9. As the start of injection is retarded, the ignition timing and peak temperature are delayed and decreased, respectively. According to the start of injection, ignition timing has a range between BTDC 5 degree and ATDC 5 degree. Also, the slightly decreasing section of mean gas temperature appeared before the ignition due to the latent heat of injected fuel evaporation.

\subsection{Emission Characteristics of DME Engine}

In order to analyze emission characteristics of DME combustion, the reduced GRI NO mechanism and detailed chemical kinetics model were used to calculate the $\mathrm{NO}_{x}$ and $\mathrm{CO} / \mathrm{HC}$ emissions.

Calculated $\mathrm{NO}_{x}$ emission distributions of coarse and fine grid meshes for the BTDC 10 degree injection case from the TDC to ATDC 12 degrees are illustrated in Figure 10. The distribution of $\mathrm{NO}_{x}$ emission in the cylinder shows a pattern similar to the temperature distribution in Figure 8. This is because $\mathrm{NO}_{x}$ emissions are greatly affected by the combustion temperature and then they are actively formed in the combustion region of high temperature. Moreover, the wide spatial distribution with high temperature in the fine grid mesh has an influence on the $\mathrm{NO}_{x}$ emission distribution. Therefore, the $\mathrm{NO}_{x}$ emission distribution in the fine grid mesh shows a wider spatial distribution with high level compared to that in the coarse grid mesh. In addition, ignition occurred in the region of the right bowl because a rich region of air-fuel mixture is created by the impingement on the wall of evaporated fuel and fuel atomization at the spray tip. After the ignition, the combustion progressed along to the bowl wall because the flow in the cylinder was formed by high injection velocity at the nozzle exit. For this reason, the high density of $\mathrm{NO}_{x}$ emission distribution appears at the surface of the bowl wall. 


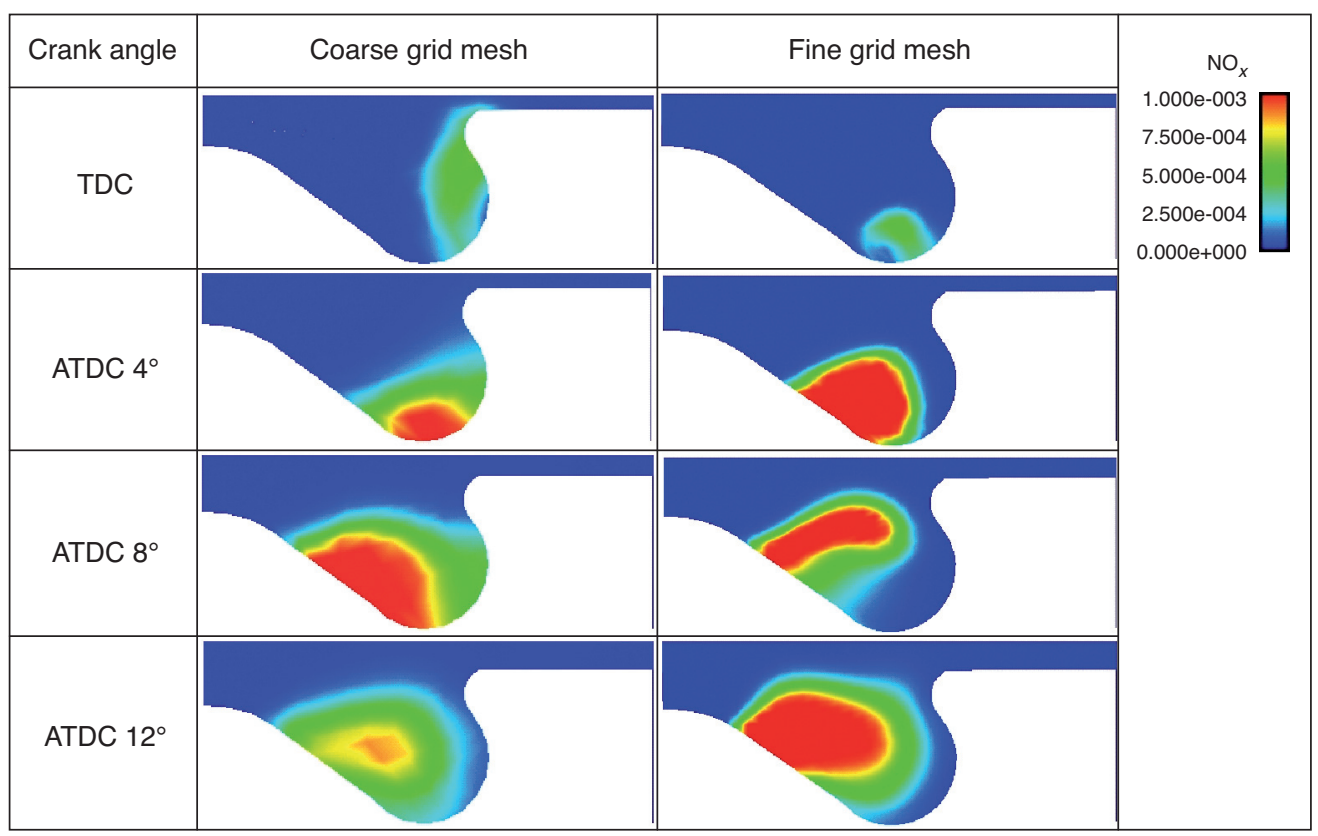

Figure 10

Calculated $\mathrm{NO}_{x}$ emissions distribution of coarse and fine grid meshes according to the crank angle $\left(\mathrm{SOI}=\mathrm{BTDC} 10^{\circ}\right)$.

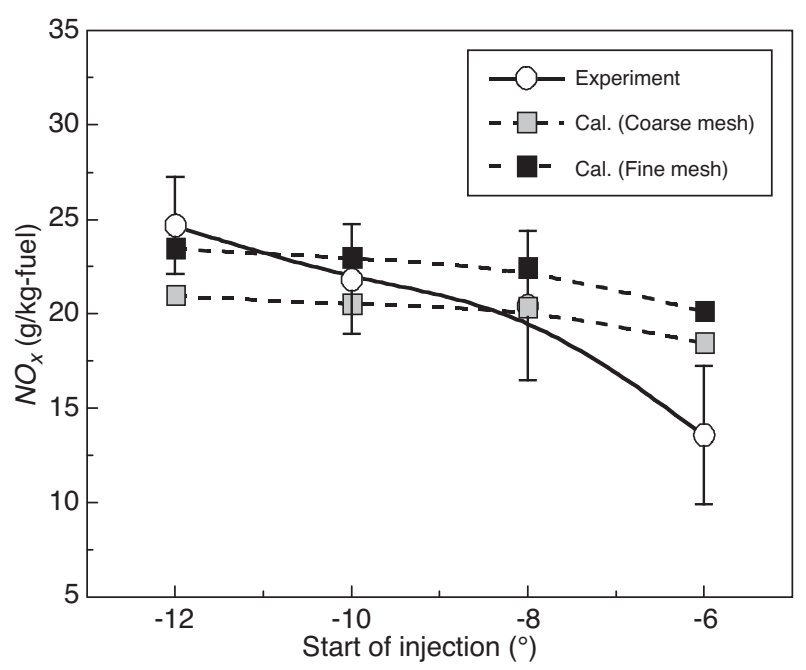

Figure 11

Comparison between experimental and calculated $\mathrm{NO}_{x}$ emission amounts according to the start of injection.

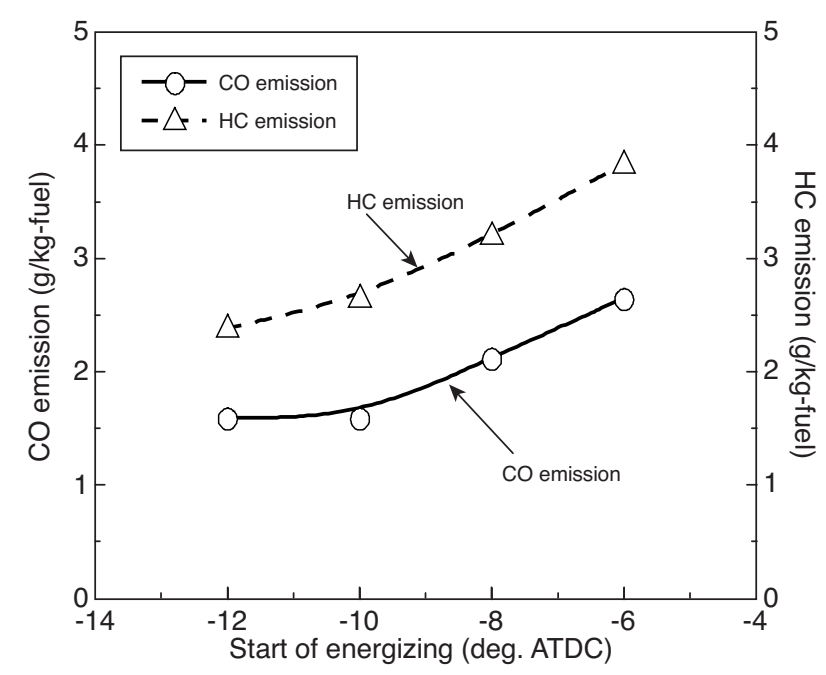

Figure 12

Calculated $\mathrm{CO}$ and $\mathrm{HC}$ emission amounts according to the start of injection.
Not only did the $\mathrm{NO}_{x}$ emission distribution progress along to the bowl wall, but it also widely spread throughout the cylinder as time elapsed.

Figure 11 shows the comparison between experimental and calculated $\mathrm{NO}_{x}$ emissions according to the start of injection. $\mathrm{NO}_{x}$ emission has a decreasing trend as the start of injection timing retarded. This is because $\mathrm{NO}_{x}$ emissions have a great influence on the temperature in the cylinder during the combustion process and then the increasing mean gas temperature by the advanced injection timing led to the large $\mathrm{NO}_{x}$ emission amounts. Further, the decreasing trend of experimental results is more sensitive to start of injection than that of numerical results. It is guessed that this difference between experimental and numerical results was caused 
by the effect of residual gas in the experiment and ignition delay in the calculation. In the case of the experiment, the residual gas in the cylinder remained after the combustion process. The residual gas hindered the active combustion due to the decrease of intake air amount and this caused the low $\mathrm{NO}_{x}$ amount of the experimental results. In case of the numerical results, the ignition timing slightly advanced compared to that of the experimental results. The advanced ignition timing led to the higher $\mathrm{NO}_{x}$ emission than that of the experimental results. On the other hand, the fine grid mesh has a higher $\mathrm{NO}_{x}$ amount than the coarse mesh as shown in the following figure because the momentum transfer in the cell was affected by the velocity and flow of injected droplets within the nearest cell. Further, the evaporated fuel and droplets in the fine grid diffused more than those in the coarse grid before the fuel was ignited. Therefore, the combustion in the fine grid occurred from wider spatial distribution compared to that of the coarse grid.

The calculated $\mathrm{CO}$ and $\mathrm{HC}$ emissions according to the start of the injection are represented in Figure 12. The calculated $\mathrm{CO}$ and $\mathrm{HC}$ emissions show an increasing trend as the start of the injection is retarded. Generally, $\mathrm{CO}$ and $\mathrm{HC}$ emissions are a representative product of incomplete combustion. Further, the combustion actively happened as the start of the injection was advanced because there was enough time for the mixed gas between evaporated fuel and ambient air. In the results of Figures 7 and 9, the combustion pressure and temperature have high peak value as the start of the injection was advanced. Therefore, the calculated $\mathrm{CO}$ and $\mathrm{HC}$ emissions according to the start of the injection show a general tendency.

\section{CONCLUSIONS}

In the present study, the investigations on the modeling on the combustion and emission characteristics of DME fuel at various starts of the injection in a single cylinder diesel engine with a common-rail injection system were conducted by using the KIVA-3V code coupled with a detailed DME oxidation mechanism. The calculated results, such as combustion pressure, heat release rate, and exhaust emissions are compared and analyzed with experimental results under the same operating conditions. From the results of this investigation, the conclusions are summarized as follows.

In model validation, the calculated combustion pressure and ignition timing agreed with experimental results. The combustion pressure and heat release rates of diesel fuel showed higher peaks than those of DME fuel at the same injection mass. The ignition timing of DME fuel was more advanced than that of diesel fuel because DME fuel has a high cetane number and faster evaporation than diesel fuel.

In the spray characterisitics, wall-wetting appeared with the diesel spray due to the impingement with the bowl wall of the piston but DME spray evaporated before the impingement.
As the start of the injection was advanced, the experimental combustion pressure and ignition timing are increased and advanced, respectively. This pattern of experimental results agreed with model predictions. Also, the mean gas temperature after fuel injection decreased slightly due to the latent heat of evaporation.

In the emission characteristics, the $\mathrm{NO}_{x}$ emission distribution spread throughout the cylinder and progressed along the bowl wall with elapsed time. $\mathrm{NO}_{x}$ emission had a decreasing trend as the start of injection timing was retarded, corroborating calculated results. Additionally, the calculated $\mathrm{CO}$ and $\mathrm{HC}$ emissions show an increasing trend as the start of the injection is retarded.

\section{ACKNOWLEDGMENTS}

This study was supported by the CEFV (Center for Environmentally Friendly Vehicles) of the Eco-STAR project from the MOE (Ministry of Environment, Republic of Korea). This work was supported by grant No. KRF-2008-314D00056 from the Korea Research Foundation. Also, this work was supported by the Second Brain Korea 21 Project in 2007.

\section{REFERENCES}

Amsden AA. (1999) KIVA-3V release 2. Improvement to KIVA3V, Los Alamos National Laboratory. LA-UR-99-915.

An S.G., Kim M.Y., Yoon S.H., Lee J.H., Lee C.S. (2007) Combustion and exhaust emission characteristics of DME in a common-rail diesel engine, Trans. KSAE 15, 2, 74-80.

Arcoumanis C., Bae C., Crookes R., Kinoshita E. (2008) The potential of di-methyl ether (DME) as an alternative fuel for compression-ignition engines: A review, Fuel 87, 7, 1014-1030.

Beale J.C., Reitz R.D. (1999) Modeling spray atomization Kelvin-Helmholtz/Rayleigh-Taylor hybrid model, Atomization Sprays 9, 623-650.

Curran H.J., Fischer S.L., Dryer F.L. (2000) The reaction kinetics of dimethyl ether. II: low temperature oxidation in flow reactors, Int. J. Chem. Kinet. 32, 741-759.

Dagaut P., Boettner J.-C., Cathonnet M. (1996) Chemical kinetic study of dimethylether oxidation in a jet stirred reactor from 1 to 10 atm: experiments and kinetic modeling, Twenty-Sixth Symposium (International) on Combustion/The Combustion Institute, pp. 627-632.

Dagaut P., Daly C., Simmie J.M., Cathonnet M. (1998) The oxidation and ignition of dimethylether from low to high temperature (500-1600 K): experiments and kinetic modeling, Twenty-Seventh Symposium (International) on Combustion/The Combustion Institute, pp. 361-369.

Elkelawy M., Zhang Y., Alm El-Din H., Yu J. (2008) Detailed simulation of liquid DME homogenization and combustion behaviors in HCCI engines, SAE paper 2008-01-1705.

Fischer S.L., Dryer F.L., Curran H.J. (2000) The reaction kinetics of dimethyl ether. I: high temperature pyrolysis and oxidation in flow reactors, Int. J. Chem. Kinet. 32, 713-740.

Gui B., Chan T.L., Leung C.W., Xiao J., Wang H., Zhao L. (2004) Modeling study on the combustion and emissions characteristics of a light-duty DI diesel engine fueled with dimethyl ether (DME) using a detailed chemical kinetics mechanism, $S A E$ paper 2004-01-1839. 
Han Z., Reitz R.D. (1995) Turbulence modeling of internal combustion engines using RNG k-e models, Combust. Sci. Technol. 106, 267-295.

Jun L., Sato Y., Noda A. (2001) An experimental study on DME spray characteristics and evaporation processes in a high pressure chamber, SAE paper 2001-01-3635.

Jung G.S., Sung Y.H., Choi B.C., Lim M.T. (2009) Effects of mixture stratification on HCCI combustion of DME in a rapid compression and expansion machine, Int. J. Automotive Technol. 10, 1, 1-7.

Kee R.J., Rupley F.M., Miller J.A. (1989) CHEMKIN-II: a fortran chemical kinetics package for the analyses of gas phase chemical kinetics, Sandia Report, SAND 89-8009.

Kim H., Cho S., Min K. (2003) Reduced chemical kinetic model of DME for HCCI combustion, SAE paper 2003-01-1822.

Kim H.J., Suh H.K., Park S.H., Lee C.S. (2008a) An experimental and numerical investigation of atomization characteristics of biodiesel, dimethyl ether, and biodiesel-ethanol blended fuel, Energ. Fuel. 22, 2091-2098.

Kim H.J., Suh H.K., Lee C.S. (2008b) Numerical and experimental study on the comparison between diesel and dimethyl Ether (DME) spray behaviors according to combustion chamber shape, Energ. Fuel. 22, 2851-2860.

Kim H.J., Ryu B.W., Lee C.S. (2008c) Modelling for investigation of combustion and emission characteristics in a high-speed directinjection diesel engine with light duty under various operating conditions, Proc. IMechE Part D: J. Automobile Engineering. 222, 2159-2170.

Kim H.J., Park S.H., Suh H.K., Lee C.S. (2009) Atomization and evaporation characteristics of biodiesel and dimethyl ether compared to diesel fuel in a high-pressure injection system, Energ. Fuel. 23, 1734-1742.

Kim M.Y., Bang S.H., Lee C.S. (2007a) Experimental investigation of spray and combustion characteristics of dimethyl ether in a common-rail diesel engine, Energ. Fuel. 21, 793-800.

Kim M.Y., Yoon S.H., Park K.H., Lee C.S. (2007b) Effect of multiple injection strategies on the emission characteristics of dimethyl ether (DME)-fueled compression ignition engine, Energ. Fuel. 21, 2673-2681.

Kim M.Y., Yoon S.H., Ryu B.W., Lee C.S. (2008) Combustion and emission characteristics of DME as an alternative fuel for compression ignition engines with a high pressure injection system, Fuel 87, 2779-2786.

Kong S.-C. (2007) A study of natural gas/DME combustion in HCCI engines using CFD with detailed chemical kinetics, Fuel 86, 1483-1489.

Kong S.C., Sun Y., Reitz R.D. (2007) Modeling diesel spray flame lift-off, sooting tendency and NOx emissions using detailed chemistry with phenomenological soot model, J. Eng. Gas Turbine Power 129, 252-260.

Konno M., Chen Z., Miki K. (2003) Computational and experimental study on the influence of formaldehyde on HCCI combustion fueled with dimethyl ether, SAE paper 2003-01-1826.

Mittal G., Chaos M., Sung C., Dryer F.L. (2008) Dimethyl ether autoignition in a rapid compression machine: Experiments and chemical kinetic modeling, Fuel Process. Technol. 89, 1244-1254.

Mo C., Zhang Y., Shi Y., Han J., Sun H. (2007) Experimental and numerical study on emission in an HCCI engine operated with neat dimethyl ether, SAE paper 2007-01-1888.
O'Rourke P.J., Amsden A.A. (2000) A spray/wall interaction submodel for the KIVA-3 wall film model, SAE paper 2000-01-0271.

Park S.W., Reitz R.D. (2007) Numerical study on the low emission window of homogeneous charge compression ignition diesel combustion, Combust. Sci.Technol.179, 2279-2307.

Park S.W., Reitz R.D. (2009) Optimization of fuel/air mixture formation for stoichiometric diesel combustion using a 2-spray-angle group-hole nozzle, Fuel 88, 843-852.

Patel A., Kong S.C., Reitz R.D. (2004) Development and validation of a reduced reaction mechanism for HCCI engine simulations, SAE paper 2004-01-0558.

Smith G.P., Golden D.M., Frenklach M., Moriarty N.W., Eiteneer B., Goldenberg M. et al. (2000) <http://www.me.berkeley.edu/gri_mech>.

Sidu X., Mingfa Y., Junfeng X. (2001) An experimental investigation on the spray characteristics of dimethyl ether(DME), SAE paper 2001-01-0142.

Sun Y., Reitz R.D. (2006) Modeling diesel engine NOx and soot reduction with optimized two-stage combustion, SAE paper 200601-0027.

Teng H., McCandless J.C. (2005) Comparative study of characteristics of diesel-fuel and dimethyl-ether sprays in the engine, $S A E$ paper 2005-01-1723.

Teng H., McCandless J.C., Schneyer J.B. (2001) Thermochemical characteristics of dimethyl ether-An alternative fuel for compression-ignition engines, SAE paper 2001-01-0154.

Teng H., McCandless J.C., Schneyer J.B. (2002) Viscosity and lubricity of (liquid) dimethyl Ether-An alternative fuel for compression-ignition engines, SAE paper 2002-01-0862.

Teng H., McCandless J.C., Schneyer J.B. (2003) Compression ignition delay (physical + chemical) of dimethyl ether-An alternative fuel for compression-ignition engines, SAE paper 2003-01-0759.

Teng H., McCandless J.C., Schneyer J.B. (2004) Thermodynamic properties of dimethyl ether-An alternative fuel for compressionignition engines, SAE paper 2004-01-0093.

Tsutsumi Y., Iijima A., Yoshida K., Shoji H., Lee J.T. (2009) HCCI comsbution characteristics during operation on DME and methane fuels, Int. J. Automotive Technol. 10, 6, 645-652.

Yamada H., Sakanashi H., Choi N., Tezaki A. (2003) Simplified oxidation mechanism of DME applicable for compression ignition, SAE paper 2003-01-1819.

Yamada H., Suzaki K., Sakanashi H., Choi N., Tezaki A. (2005) Kinetic measurements in homogeneous charge compression of dimethyl ether: role of intermediate formaldehyde controlling chain branching in the low-temperature oxidation mechanism, Combust. Flame 140, 24-33.

Zhang Y., Mo C., Sun H., Zhou S. (2007) Study on formaldehyde emission in a DME-fueled direct-injection diesel engine, SAE paper 2007-01-1909.

Zheng X.L., Lu T.F., Law C.K., Westbrook C.K., Curran H.J. (2005) Experimental and computational study of nonpremixed ignition of dimethyl ether in counterflow, Proc. Combust. Inst. 30, 1101-1109.
Final manuscript received in March 2011 Published online in May 2012

\section{Copyright (C) 2012 IFP Energies nouvelles}

Permission to make digital or hard copies of part or all of this work for personal or classroom use is granted without fee provided that copies are not made or distributed for profit or commercial advantage and that copies bear this notice and the full citation on the first page. Copyrights for components of this work owned by others than IFP Energies nouvelles must be honored. Abstracting with credit is permitted. To copy otherwise, to republish, to post on servers, or to redistribute to lists, requires prior specific permission and/or a fee: Request permission from Information Mission, IFP Energies nouvelles, fax.+33147527096, or revueogst@ifpen.fr. 